\title{
Professional Asian Football Leagues and the Global Market
}

\author{
Stefan SZYMANSKI
}

University of Michigan

This paper considers the development potential for professional football (soccer) leagues in Asia. This is set in the context of a global market where playing talent is easily bought and sold, and fans are attracted by the highest quality of play which they mostly consume via screens. The paper highlights the relative underdevelopment of Asian leagues given the size and growing economic power of the Asian markets, and suggests some ways in which this might change in the future.

Key words: football, professional league, soccer, sport

JEL codes: Z21, Z28

\section{Introduction}

Fifty years ago, if you were a supporter of Liverpool Football Club living in Asia, and you wanted to know how they had fared in the FA Cup played at Wembley in England, your best bet would have been to look in your local newspaper the following day (they beat Leeds 2-1 in 1965). Twenty-five years ago or so, in much of Asia you would still have needed to consult the newspaper, but in some countries at least you probably could have watched it live on TV, possibly in a local bar (they beat Sunderland 2-0 in 1992). In 2015, Liverpool lost the semi-final to Aston Villa, a game that you could easily have watched live on your mobile phone throughout most of Asia. Of course, you might not be that bothered, since the FA Cup is not the prestigious tournament it was even 25 years ago, and Liverpool fans care much more about qualifying for the Champions League, which did not exist a quarter of century ago. But the point is, 50 years ago there were many fans of English football to be found in Asia even though they had almost no opportunity to watch the games played. Today in Asia, there are still many fans of English football, and added to that there are fans of Spain's La Liga, Germany's Bundesliga and Italy's Serie A, not to mention the pan-European Champions League.

Fifty years ago, most Asian nations did not have a professional football league of their own. Now most do, but still the focus of fan interest in Asia is directed primarily at European clubs. This, I think, raises a question of great interest to economists and marketers alike. Is professional football a kind of business in which first mover advantages persist? Or, given the intense demand for professional football in Asia, will local Asian leagues evolve which can challenge the dominance of the European leagues? What factors hold back the development of football leagues in Asia, and what lessons are to be learned from the experience of other sports?

${ }^{\dagger}$ Correspondence: Stefan Szymanski, University of Michigan, 3118 Observatory Lodge, 1402 Washington Heights, Ann Arbor, MI 48109-2013, USA. Email: stefansz@umich.edu 
This paper starts with a review of the development of professional football worldwide. The evolution of Asian leagues is then described. The next section looks briefly at developments in other sports. The last section discusses prospects for future growth in Asia.

\section{The Development of Professional Football}

\subsection{History and structure}

The rules of the modern game of Association Football (henceforth football) were written down in London in 1863 by the newly created Football Association (FA), the first national football federation. The FA accepted professional players in 1885 and the first professional football league in the world, the Football League, was founded in England in 1888. The founder members consisted of only 12 teams, but a second division was added in 1892, and following the interruption of World War One, expanded to four divisions with 88 clubs in total in 1923 an organizational structure which remains almost unchanged to the present day. ${ }^{1}$ Football's popularity spread rapidly, and by 1900 the game was widely played in Europe and South America. The Hong Kong Football Association was founded in 1914. It is interesting to note that while some sports which developed in Britain, such as cricket and rugby, to this day remain associated in most peoples' eyes with British culture, this is much less true of football. Across the world, Germans, Italians, Spaniards, Argentinians, Brazilians, and so on have developed their own football culture which owes little to the game's British origins. Indeed, arguably it is only in this way the football has been able to develop into the world's game. ${ }^{2}$

Organizationally, however, it took some considerable time for other countries to catch up with the British lead. Most European and South American nations had established a national federation by 1900, and Fédération Internationale de Football Association (FIFA), the world governing body, was founded in 1904. In those early years, teams from England and Scotland regularly toured the world, and typically notched up substantial victories. British players and British coaches were in high demand around the world at least until the 1950s. While there were some early professional leagues in Europe - Italy and the Netherlands in 1898 - most were founded between the wars (Spain 1929, Argentina 1931, France 1933, Portugal 1935), and some national leagues are remarkably recent (Germany 1963, Brazil 1971).

League development took place largely on national lines, a consequence of a governance structure formed around national federations. Each nation tended to establish a hierarchy of leagues, connected through the system of promotion and relegation. In England there developed a significant degree of rivalry between the national federation (the FA) and the Football League; even though the League acknowledged the sovereignty of the FA, it still sought to maintain a clear demarcation of powers and to sustain a degree of autonomy. In most other countries, however, the links between the national league and governing body were very strong, often consisting of largely the same people. This connection has generally been strengthened by a shared concern over the success of 
the national team. While international play dates back to 1871, it was the inauguration of the World Cup in 1930 which helped to ensure a continuing national focus.

One feature of the football world that is striking is the simultaneous interest in national team/international competition and club/league competition. In most professional sports, both forms of competition usually exist, but only one form is dominant. For example, American sports such as baseball, American football, and basketball have developed extremely successful leagues and teams, but there is almost no interest in international team competition. This is obviously true for American football which is played almost nowhere else, but also largely true for baseball, and to a lesser extent basketball. By contrast, sports such as cricket and rugby union (which have remained extremely popular not only in Britain, where they originated, but also in the Commonwealth of Nations), are popular only with respect to national team competition. For example, while the recently completed Cricket World Cup commands significant interest both on TV and at the stadiums, national leagues in most cricket nations attract negligible interest. In general, fans appear to have an appetite only for one form of competition, and, in particular, where national team competition is dominant, the club level game struggles to make an impact. The fact that this is not the case for football may simply reflect the overpowering interest in the game.

Another aspect in which the role of national federations has been critical has been the creation of national league pyramids connected through the system of promotion and relegation. For example, in England, 24 four separate levels of competition can be identified, consisting of around 7000 teams, 5000 clubs, 140 leagues operating in 480 divisions. In principle, it would be feasible to start a club and enter at the 24 th level, and then, if promoted every season, play in the Premier League a quarter of a century later. ${ }^{3}$ Below, the fifth tier leagues are organized on a regional basis. Of course, the vast majority of players within this system are amateurs, with only the top four divisions being fully professional. Although England has one of the most extensive systems, similar arrangements exist in most countries. This is very different from the closed league systems that typify American sports. League organizations more closely resemble joint ventures organized by team owners, potentially in competition with rival leagues. Even in college sports, which although amateur in name, command large audiences and generate large revenue streams, there is no mechanism for teams to move from one level of competition to another on a regular basis.

From an economic perspective, the organizational system of football has some important implications. It is a system in which sporting competition goes together with economic competition. Rather than thinking of league members as participants in a joint venture (as is usually the case with American professional sports leagues), one might more naturally think of them as pure rivals, like rival law firms that compete within a common legal system to attract business, with only limited incentives to cooperate with each other. In the American system, members of the leagues agree to restraints that significantly limit economic competition, either from the perspective of the labour market (e.g. salary caps, restraints on player mobility) or the product market (sharing revenues from TV broadcast contracts, stadium attendance, and merchandising). ${ }^{4}$ In soccer, such 
restraints are limited. Players are largely free to move within the system and mobility is high. Typically there is a degree of sharing of broadcast revenues, though this is seldom on the strictly equal shares basis adopted in the USA. In Spain, the two dominant clubs, Real Madrid and Barcelona have until now not shared any broadcast revenues, although they are expected to accept a degree of revenue sharing in the future.

Within the national pyramid, revenues fall significantly as one moves from higher to lower tiers. For example, the clubs in the English Premier League currently generate about seven times as much revenue as clubs in the Football League Championship, the next tier down. The Championship clubs generate about twice as much revenue as clubs in the third tier Football League One, which is in turn about twice as much as clubs in the fourth tier Football League Two. The financial reward of promotion is significant, as is the financial penalty for relegation. This reflects both lower revenues from broadcasting and sponsorship, where the money tends to be focused on the highest tier, as well as attendance and spending by fans, who are less attracted to lower division competition.

The financial implications of promotion and relegation are such that they undermine the incentive to create solidarity mechanisms such as those adopted in closed American leagues. The intensely competitive nature of the system has generated two principal outcomes: dominance and distress.

\subsection{Dominance}

In almost every country the national league is dominated by a small number of teams. The same pattern emerges whether we are talking about a big league such as Spain's La Liga, where Real Madrid has won 22 titles in the last half century, or the tiny Faroe Islands where Havnar Bóltfelag from the capital, Torshavn (population 18,000) has won 19 titles in the last half century. Table 1 shows that in most leagues one team alone has won between one third and one half of all the championships over the last half century, while over the same period there have been fewer than 13 different champions in most countries. In the Netherlands, Portugal, Scotland, and Turkey, there were five or fewer champions. To put it another way, over half a century the three most successful teams in each country accounted for more than two thirds of the championships won.

The fact that dominance has characterized football leagues across the world for so long is perhaps surprising to those familiar with the sports economics literature. In that literature, it is conventional to argue that sport is interesting to consumers only when it entails "uncertainty of outcome" and that to achieve this, a level of "competitive balance" among the competing teams is necessary. While one might argue about the level of balance that is necessary, it is usually taken for granted that a more balanced league will be more popular than a less balanced league (the theory is discussed in detail in Szymanski [2003]).

\subsection{Distress}

In every country, there is a long history of financial distress among football clubs. For example, in 2010, 18 professional Italian football clubs were liquidated after being sanctioned by the league for failing to meet their financial obligations. In May 2014, the 
Table 1 Dominance in 20 European leagues over the last 50 years

\begin{tabular}{llll}
\hline & & $\begin{array}{l}\text { Most league } \\
\text { championship } \\
\text { wins in last 50 years }\end{array}$ & $\begin{array}{l}\text { Number of league } \\
\text { championship } \\
\text { winners in last 50 years }\end{array}$ \\
\hline England & revenue 2012 €m & 15 & 11 \\
Germany & 139 & 23 & 12 \\
Spain & 108 & 22 & 7 \\
Italy & 93 & 18 & 11 \\
France & 86 & 8 & 14 \\
Russia & 58 & 13 & 14 \\
Turkey & 56 & 17 & 5 \\
Netherlands & 31 & 23 & 5 \\
Switzerland & 24 & 16 & 11 \\
Portugal & 19 & 22 & 4 \\
Norway & 18 & 22 & 12 \\
Scotland & 11 & 24 & 5 \\
Poland & 10 & 9 & 12 \\
Romania & 6 & 19 & 11 \\
Hungary & 6 & 11 & 11 \\
Finland & 2.3 & 16 & 14 \\
Republic of Ireland & 1.6 & 7 & 15 \\
Luxembourg & 0.9 & 20 & 11 \\
Faroe Islands & 0.6 & 19 & 11 \\
Champions League & 0.4 & 12 & \\
\hline
\end{tabular}

Source: Szymanski (2015).

Spanish Secretary of State for Sport Miguel Cardenal revealed that professional clubs in the country's First and Second Division have accumulated debts of $€ 3.6$ billion, including $€ 752$ million owed by clubs to the Treasury, which they were almost certainly unable to repay. In England, 70 professional clubs in the top four divisions have entered legal insolvency proceedings since 1982. The first known football club insolvency in England was Middlesbrough Ironopolis that was liquidated in 1893. Even in countries like Germany, which are reputed to enjoy sounder financial management, insolvency is common in the lower divisions. Research by Daniel Weimar of the University of Duisburg-Essen found 86 cases of football clubs in lower divisions entering insolvency since 1993, a rate of almost four per year. Union of European Football Associations (UEFA), the governing body of European football found that in the financial year 2012, $39 \%$ of European top division clubs had negative equity - meaning that their liabilities exceeded their assets, usually taken as a sign of impending insolvency. Since 2008, UEFA has reported the proportion of clubs whose auditors raised a "going concern" issue meaning that without some additional assumptions one could not be confident, based 
on the accounting data alone, that the club would not become insolvent in the coming year. Between 2008 and 2011, the fraction of clubs whose accounting information was qualified in this way rose from $10 \%$ to $14 \%$. In 2012, UEFA did not reveal the percentage.

\subsection{Markets}

The pattern of dominance and distress can be accounted for by the nature of the competitive system. Two essential facts about football markets are clear. First, money buys talent, and talent is widely recognized in football. There are many buyers and sellers and the performance of players is constantly observed - the football labour market more closely resembles the benchmark of perfect competition than it does the now standard labour market models where there is asymmetric information and market failure. Second, as mentioned above, failure in competition leads to falling revenues - fans follow success. The relative efficiency of these two markets can be illustrated using audited accounting data from English football.

Figure 1 shows the relationship between club spending on wages, from the audited financial accounts of the clubs, and league position in the four top divisions (92 clubs) between 1958 and 2013. Each dot represents the wage/position pair for a club in a given season. While there are many outliers, it is clear that there is a strong correlation between pay and performance. This does not mean that higher pay elicits more effort (most professional players are highly dedicated and do not need much by way of financial incentives to perform) but that players tend to fairly priced in the market. In other words, if a

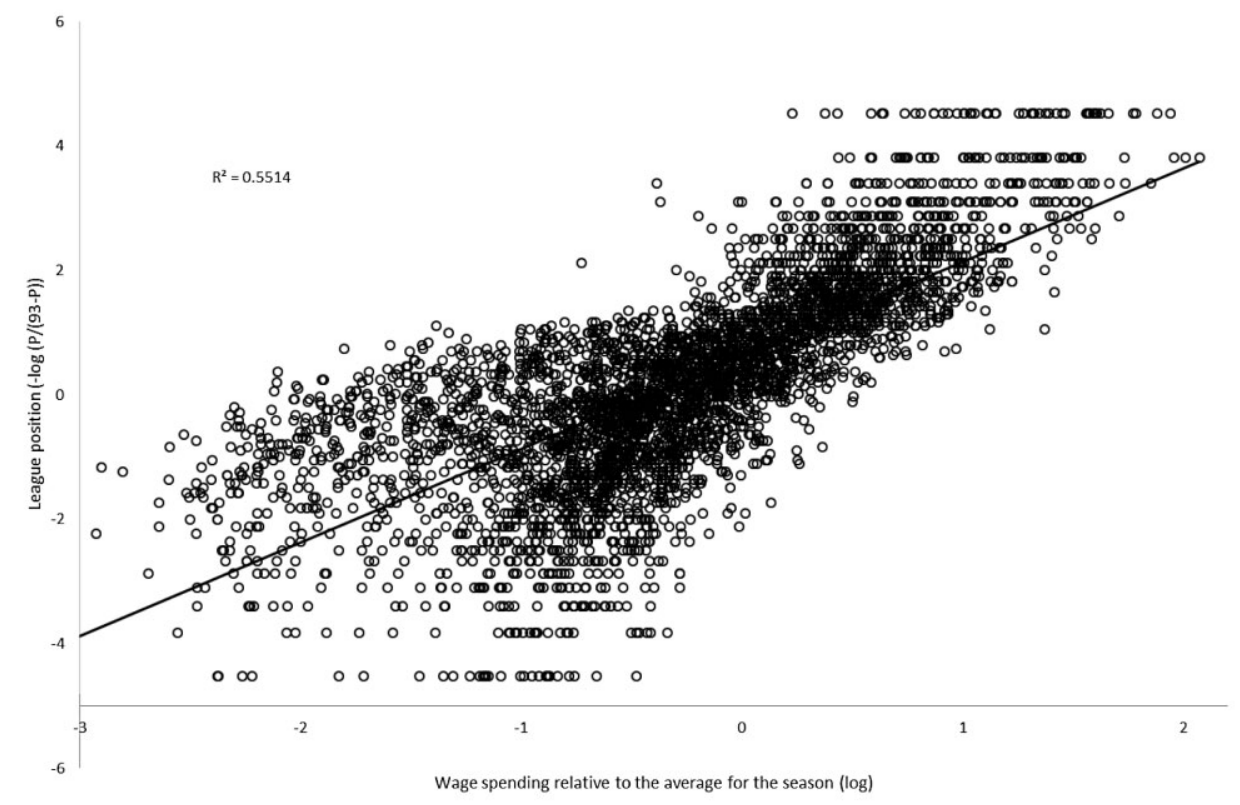

Figure 1 The wage performance relationship in England 1958-2013. Source: Szymanski (2015). 
player of given talent is paid less by his current club than comparable players elsewhere, he will tend to be bid away by a rival club. Better players are more likely to win and so tend to be paid more. The $R^{2}$ of the regression in Figure 1 is 0.55 , suggesting that only $45 \%$ of the variation in league performance - less than half - can be accounted for by all other factors combined, including factors such as luck and managerial skill. It seems plausible to argue that wage spending is the dominant factor determining club performance. Moreover, because of what we know about the market for players, there are good theoretical grounds to believe that this relationship is causal. ${ }^{5}$

The dependence of revenues on league performance is illustrated in Figure 2, which again uses audited accounting data from the top four divisions in England from 1958 to 2013. Revenues are expressed relative to the average in the league for that season. In this case about $60 \%$ of the relative income of the clubs in each season can be explained simply by league position. If the relative income of clubs is averaged over a period of years, essentially averaging out random fluctuations from season to season, the percentage of variation explained rises to $90 \%$. Even if many fans are loyal to a team, there are also many casual fans who become more interested as teams become more successful. Not only does ticket revenue rise with success, but fans also spend on merchandising shirts, scarves, etc. In modern times, broadcast income has become increasingly important as a source of revenue, and this tends to increase when clubs become more successful, a fact generally reflected in the distribution formula for league broadcast contracts. There is usually a noticeable decline when going from the top tier to the second

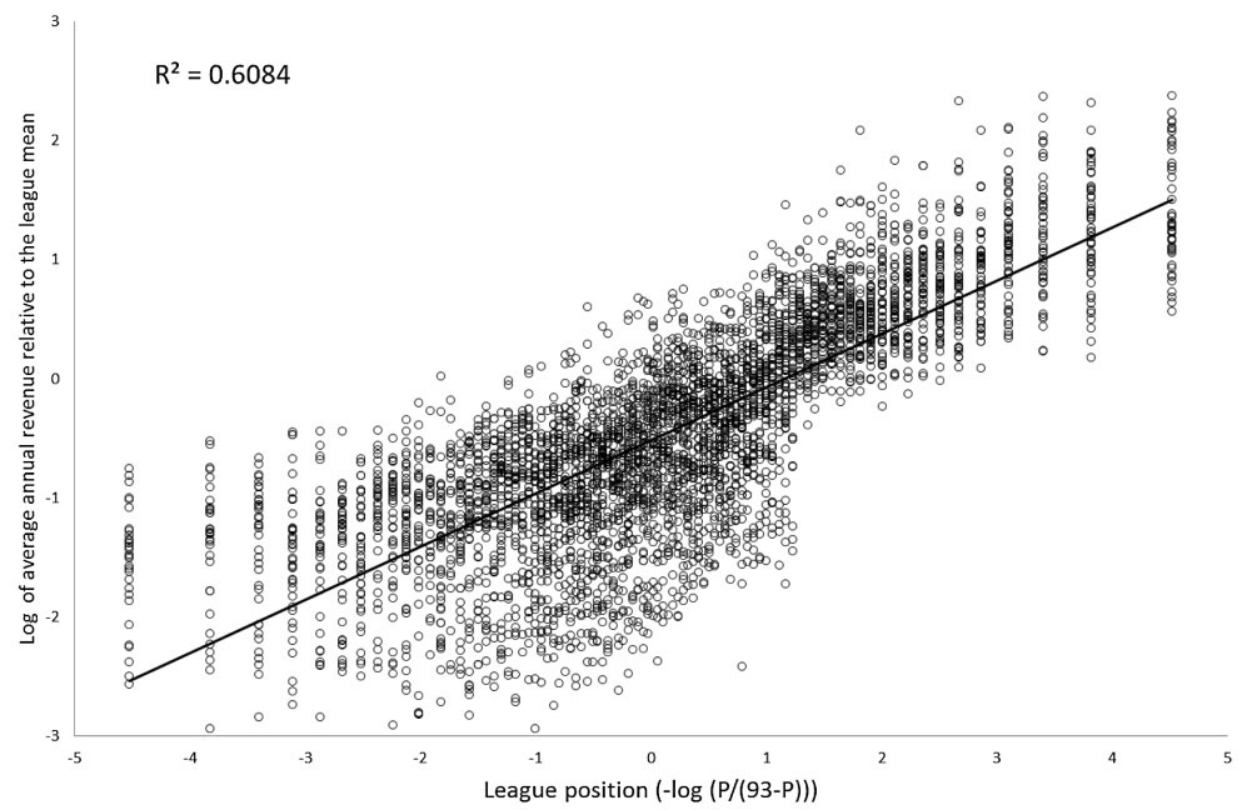

Figure 2 Revenue and league position in the four English divisions 1958-2013. Source: Szymanski (2015). 
tier, since TV audiences are almost exclusively focused on the highest level of competition. Finally, sponsorship revenues are also very sensitive to league performance, since sponsors obviously want to be associated with successful clubs. They also gain much more, and will therefore pay much more, when a club is in the top division and receiving significant exposure on TV.

\subsection{Global hierarchy}

The structure of competition and the competitiveness of the markets have created a situation in world football where each league tends to be dominated by a small number of clubs. Broadcasting technology has also established hierarchy of leagues. Games started to be shown internationally in the 1960s (the 1966 World Cup was estimated to have been watched by 400 million viewers worldwide), but the regular broadcasting of national leagues in foreign countries only gathered pace in the 1980s, when Italy's Serie A came to be seen as the dominant league globally. At the time a majority of the world's best players were to be found in Serie A, and the international mix made it attractive. Since the 1980s, following leagues in other countries has become the norm. Serie A has been displaced as the wealthiest league by the English Premier League.

The Premier League has benefited from the confluence of a remarkable number of favorable conditions. As the oldest league, with clubs whose international familiarity was established up to a hundred years ago when British cultural and economic influence and recognition around the globe was far greater, they have a foundation on which to build. British football has become very open to foreign influence, so that people in other countries often have some local hero with whom they are familiar. British football has also been very open to foreign investment, which has enabled clubs to acquire talent. The style of play in England, although not always of highest quality in technical terms, is fast paced and attractive on TV. Even more coincidentally, the timing of games in England - played between midday and 6 PM GMT at the weekends, means that live viewing is possible in most parts of the world without staying up late into the night - this has been a particularly important issue in selling the Premier League to audiences in East Asia. The Premier League not only has the largest domestic TV broadcast contract of any league in the world (the latest 3-year deal announced in February 2015 is worth $\$ 8$ billion) but also by far the largest overseas TV rights revenues. For a decade now, the English Premier League (EPL) has generated close to half of its broadcast income from overseas sales - most other leagues in the world, in any sport, struggle to generate as much as $10 \%$ from overseas sales.

The dominance of the biggest European clubs has also been enhanced by UEFA's Champions League, a competition that has grown in the shadow of the threat by the biggest clubs to break away and form their own league. Under this threat, the competition has become a global showcase for the biggest European clubs and also source of significant income that helps to maintain the gap in spending power with their domestic rivals.

It is fairly easy to write down the global pecking order of football clubs. Table 2 ranks the top 20 football clubs by their annual revenues in 2014. Real Madrid (first) and 
Table 2 The top 20 global football clubs by revenues (fiscal year 2014)

\begin{tabular}{|c|c|c|c|c|}
\hline Rank & Club & Revenue €m & Facebook likes & Twitter followers \\
\hline 1 & Real Madrid & 550 & 80.7 & 14.4 \\
\hline 2 & Manchester United & 518 & 63.9 & 4.2 \\
\hline 3 & Bayern Munich & 488 & 26.3 & 1.8 \\
\hline 4 & Barcelona & 485 & 81.4 & 13.8 \\
\hline 5 & Paris St. Germain & 474 & 16.3 & 1.9 \\
\hline 6 & Manchester City & 414 & 18 & 2.3 \\
\hline 7 & Chelsea & 388 & 40.4 & 5 \\
\hline 8 & Arsenal & 359 & 31.9 & 5.2 \\
\hline 9 & Liverpool & 306 & 24.9 & 3.8 \\
\hline 10 & Juventus & 279 & 16 & 1.6 \\
\hline 11 & Borussia Dortmund & 262 & 11.9 & 1.4 \\
\hline 12 & AC Milan & 250 & 24 & 2.4 \\
\hline 13 & Tottenham & 216 & 6.1 & 1 \\
\hline 14 & Schalke 04 & 214 & 2.5 & 0.3 \\
\hline 15 & Atletico Madrid & 170 & 9.8 & 1.4 \\
\hline 16 & Napoli & 165 & 3.3 & 0.5 \\
\hline 17 & Internazionale & 164 & 4.7 & 0.7 \\
\hline 18 & Galatasaray & 162 & 13.3 & 4.8 \\
\hline 19 & Newcastle & 155 & 1.5 & 0.5 \\
\hline 20 & Everton & 144 & 1.8 & 0.5 \\
\hline
\end{tabular}

Source: Deloitte Football Money League 2015.

Barcelona (fourth) have dominated Spanish football and European competition since the 1950s. Manchester United (second), Arsenal (eighth), and Liverpool (ninth) have been dominant English clubs since at least the 1960s, Bayern Munich (third) has dominated the Bundelsliga since its foundation. Juventus (10th), AC Milan (12th) and Internazionale (17th) have dominated Italian football since the 1930s and Galatasaray (18th) has been dominant since the foundation of Turkish football. Thus, half of the list consists of traditionally dominant clubs. Several other clubs - Chelsea, Manchester City, Paris St. Germain, Napoli - although having distinguished histories in their own right, are in the list primarily because in recent years that have bankrolled by wealthy owners who have bought heavily in the player markets. Three of the English clubs are there primarily because of the size of the Premier League broadcast contracts - and in future years even more of the list will be made up by English clubs. All of the clubs play in Europe - because European leagues attract the highest revenues and therefore attract the best players from all over the world. Moreover, there is a very high correlation between the following of these clubs as measured by social media and their revenues. For example, the correlation between revenues and Facebook likes is +0.81 . 


\subsection{Endogenous sunk costs and football leagues}

One explanation for the pattern of dominance that we observe in football can be drawn from the work of John Sutton in his well-known book, Sunk Costs and Market Structure (Sutton, 1991). Sutton's aim is to explain the fact that many markets for consumer products are dominated by a small number of firms, despite the fact that fixed costs associated with technology do not appear to pose a significant barrier to entry. His explanation is that in many cases it is advertising that represents the entry barrier.

Advertising is a sunk cost, but is also at the discretion of the firm (hence endogenous, unlike the set up costs of building, say, a power station necessary to compete in the supply of electricity - which are thus exogenous sunk costs). Sunk costs represent a barrier to entry, since an incumbent firm that has already incurred sunk costs would be willing to compete at a lower price than a potential entrant that has yet to sink any costs. When sunk costs are endogenous incumbents can raise barriers to entry by increasing expenditure. For example, Coca-Cola is a brand presumably known to almost everyone on the planet and has been heavily advertised for over a century, yet Coca-Cola continue to spend about $\$ 3$ billion per year on advertising. Seen from Sutton's framework, this represents investment in entry barriers, rendering it unprofitable for potential rivals to enter the market.

Sutton analyses a number of markets of this type and shows that usually there are a small number of dominant firms that advertise intensively and operate on a large scale, alongside a competitive fringe of many companies operating on a small scale in niche markets with limited advertising. This characterization seems appropriate to football leagues, the only difference being that the dominant club invests heavily not in advertising but on players. It seems clear that dominant clubs seek to invest heavily in players regardless of their past success. Smaller clubs struggle to compete because of the scale of investment required in the short run.

Traditionally dominant clubs in England include Manchester United, Arsenal, and Liverpool, in Italy AC Milan, Internazionale and Juventus, in Spain Barcelona and Real Madrid, and Bayern Munich in Germany. However, in recent years the wealthy owners of some clubs have bought their way into the elite group. The obvious examples are Roman Abramovich at Chelsea, Sheikh Mansour at Manchester City, and the Qatar Investment Fund as Paris St. Germain. These owners have sunk in excess of $\$ 1$ billion each simply to match the dominant, established teams. Absent these resources, competing at the highest level is next to impossible.

\subsection{Government policy}

A notable feature of the development of professional soccer around the world has been the limited role that government has played. In many countries, government has never played a significant role in the development of the game. It is hard to identify, for example, any significant government contribution to the development of the game in Germany, Italy, Spain, Argentina, or Brazil. Whereas centralized communist governments have enjoyed great success in accumulating Olympic medals (East Germany and the Soviet Union in past and China in recent years), this has seldom spilled over in the 
football world. Indeed, South American nations have been dominant in football while often being perceived to have weak and unstable governments. It is tempting to hypothesize that the game of football is too individualistic to be successfully regulated and developed by government bureaucracy.

\section{The Evolution of Asian Football Leagues}

The Asian Football Confederation consists of 47 member associations and was founded in 1954. Football was played in Asia long before, and there are records of games played to the modern rules in the 19th century in India, Iran, Japan, Singapore, and Thailand among others. ${ }^{6}$ About half of the national federations can date their origins to before World War II. Japan and Taiwan were the first Asian nations to compete in the Olympic Football tournament, competing in 1936, and Indonesia (still under colonial rule of the Dutch) was the first Asian nation to compete in the World Cup in 1938.

The creation of professional leagues in Asia has come relatively late on in the history of Asian football. Table 3 shows the date of foundation of the national association and the date of foundation of the professional league. Most of the federations had been established by 1940, the main exceptions being the federations of the oil rich states of the middle east which were founded around the early 1970s. However, apart from the Hong Kong League, all the professional leagues were founded no earlier than 1970, and over half of them in the last 20 years. The average gap between the foundation of the federation and the professional league is 56 years.

Many reasons might be advanced for the slow development of professional leagues. Political disruption in the 20th century did not create a stable environment in which leagues might flourish, and for much of this era the Asian nations were relatively poor and focused on economic development. It is striking to contrast the economic fortunes of South America, where professional football developed around a century ago, to the Asian experience. For example, according to Maddison, ${ }^{7}$ in 1914 gross domestic product (GDP) per capita in Latin America was more than double that of Asia, while by 2010 they were close to parity. If domestic professional football leagues are normal goods, then it is not surprising that they are a relatively recent development in Asia. Another explanation may be that some countries were slow to develop national leagues due to the consequences of colonialism, which tended to discourage nationalism and encourage regionalism. India, for example, has long had active leagues in different parts of the country, but has struggled to create a national league.

Table 4 compares professional leagues in the five main continents for which attendance data is available. Europe clearly dominates with more than half of the leagues, nearly twice as many clubs and more than twice as many games played per season. Total attendance is almost double that of all other leagues combined. Compared with Europe, Asia has fewer than half the number of leagues, one third the number of teams, and one quarter of the number of games per season. Annual attendance is about one quarter that of the European leagues. 
Table 3 Foundation dates of National Federations and professional leagues in Asia

\begin{tabular}{|c|c|c|c|c|}
\hline Country & League & $\begin{array}{l}\text { League } \\
\text { foundation }\end{array}$ & $\begin{array}{l}\text { National } \\
\text { Federation } \\
\text { founded }\end{array}$ & Difference \\
\hline Hong Kong & Hong Kong First Division League & 1914 & 1914 & 0 \\
\hline Iran & Persian Gulf Pro League & 1970 & 1920 & 50 \\
\hline Qatar & Qatar Stars League & 1972 & 1960 & 12 \\
\hline United Arab Emirates & UAE Arabian Gulf League & 1973 & 1971 & 2 \\
\hline Saudi Arabia & Saudi Professional League & 1975 & 1956 & 19 \\
\hline Vietnam & V. League 1 & 1980 & 1962 & 18 \\
\hline South Korea & K League Classic & 1983 & 1928 & 55 \\
\hline Uzbekistan & Uzbek League & 1992 & 1992 & 0 \\
\hline Japan & J. League 1 & 1993 & 1921 & 72 \\
\hline Singapore & S. League & 1996 & 1897 & 99 \\
\hline Thailand & Thai Premier League & 1996 & 1916 & 80 \\
\hline Japan & J. League 2 & 1999 & 1921 & 78 \\
\hline China & Chinese Super League & 2004 & 1924 & 80 \\
\hline China & China League One & 2004 & 1924 & 80 \\
\hline Malaysia & Malaysia Super League & 2004 & 1933 & 71 \\
\hline Malaysia & Malaysia Premier League & 2004 & 1933 & 71 \\
\hline India & I-League & 2007 & 1937 & 70 \\
\hline Indonesia & Indonesia Super League & 2008 & 1912 & 96 \\
\hline India & Indian Super League & 2013 & 1937 & 76 \\
\hline Japan & J3 League & 2013 & 1921 & 92 \\
\hline
\end{tabular}

Source: Wikipedia.

These comparisons are even starker when one takes into account population and economic weight (GDP). The population of Asia is about four times larger than Europe, while total GDP is about the same size, giving Europe a fourfold advantage in GDP per person. The Asian leagues attract around 8400 fans to games per million of population, European leagues attract 147,000 fans per million. In Asia, there are seven professional clubs for every 100 million of population, while in Europe there are 112 per 100 million. In Asia, there are 12 professional teams for every $\$ 1$ trillion of GDP, in Europe the figure is 42. It is striking that Africa, with a much lower level of economic development than Asia, manages to have attendance rates that are almost as high relative to population size, and in fact to have many more teams relative to GDP.

The quality of league play is clearly likely to be an important factor in determining the attractiveness of a league. One can distinguish two natural aspects of quality. Objectively speaking, we can say that a team which defeats another has higher observed quality. Of course, a single observation is unlikely to be decisive, but repeated observations are informative. At the level of the league, if clubs from one league consistently 


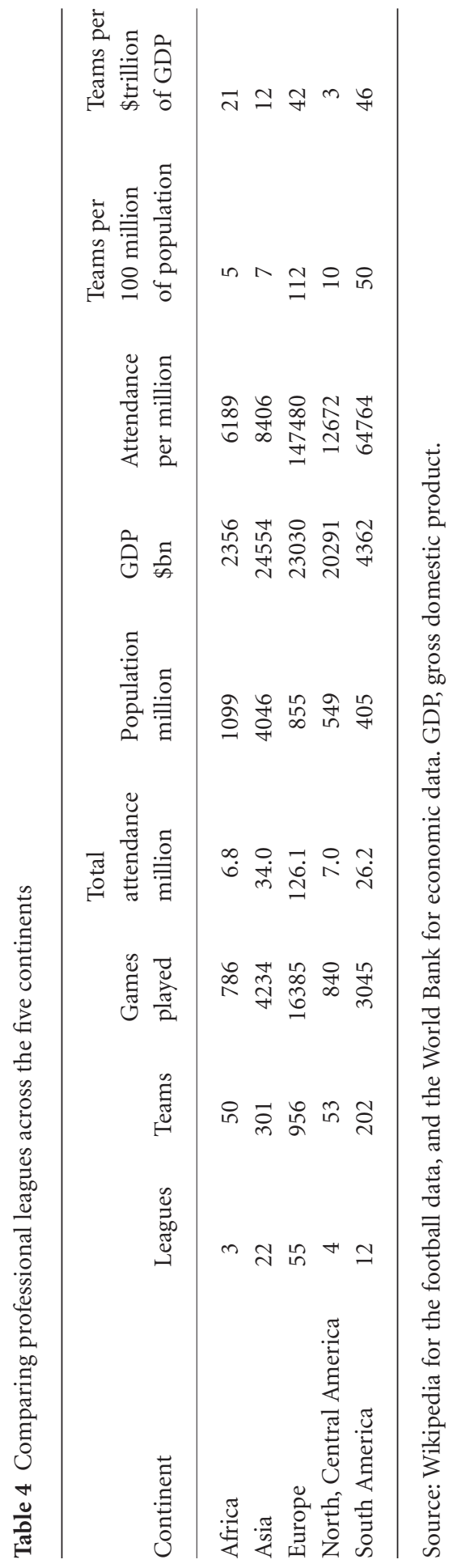


defeat clubs from another, we can say that it is objectively better. For example, clubs from Spain's La Liga, English Premier League, the German Bundesliga, and Italy's Serie A have almost completely dominated the Champions League for several decades, and few would disagree with the proposition that these four leagues are better than any others in Europe. The problem with this as a measure of quality is that we do not see consistent interaction of clubs from different leagues, especially on an intercontinental basis. However, we do observe that the market value of players is closely correlated with playing success. This was already observed for English clubs (Figure 1), and Table 5 lists the leagues according to their squad value as estimated by transfermarkt.co.uk. ${ }^{8}$ As can be seen, the top four European leagues also head the squad value rankings, which should not be surprising.

The total market value of squad players across the 76 leagues is just over $\$ 33$ billion. There are eight Asian leagues in the list (10\%) with a combined value of just over $\$ 1$ billion - only 3.5\%. The "best" Asian league on this basis, the J. League, ranked only 18 th (one place above Major League Soccer [MLS], the top league in the USA).

A second dimension of quality is purely subjective. It is possible to enjoy the level of play in a particular league even if objectively it is not the best. Other factors that may enter in that judgment include the style of play, the scheduling of competition, the history of the players (nationality, region), the nature of the rivalries between teams, and possibly many others. One way to account for some of these factors is to look for explanations for the variation in attendance at leagues.

Table 6 explores some of the factors which can account for variation in attendance at national leagues. The sample consists of 57 national leagues. The most important factor determining attendance is the market value of the players in the league. Leagues which field more valuable players have higher attendance. This is, of course, a chicken-and-egg situation. More expensive players play better football and attract larger crowds, which in turn generate larger revenues with which to pay the players. Investing in players in the hope that the crowds will come, however, represents a substantial risk, and most recently formed leagues want to build up slowly.

The regression indicates that population size and incomes (GDP per capita) constrain the level of attendance. Larger countries in particular, one might think, can sustain more clubs and therefore generate more rivalry in the league which is attractive to fans.

But perhaps, more noticeable than this is the interaction of attendance with the performance of the national team. The higher the rank of the national team, the higher the level of attendance at the national league. At first glance, this does not seem so surprising. The performance of the national stimulates interest in domestic football. ${ }^{9}$ Winning a World Cup will bring many more fans to watch the league.

However, there is only one winner at a World Cup, and most teams come home defeated. The impact that performance has on the national league is likely to depend not just on absolute performance, but performance relative to expectations. However, this is not what is being measured in the regression, since it is only the FIFA ranking that is included, not the FIFA ranking relative to the expected level. ${ }^{10}$ An alternative view is that the popularity of national leagues and of the national team are related to some other 
Table 5 Professional Football Leagues ranked by market value of squads

\begin{tabular}{|c|c|c|c|}
\hline Rank & Country & League & $\begin{array}{l}\text { Total market } \\
\text { value } \$ \mathrm{~m}\end{array}$ \\
\hline 1 & England & Premier League & 4950 \\
\hline 2 & Spain & La Liga & 3855 \\
\hline 3 & Italy & Serie A & 3165 \\
\hline 4 & Germany & 1. Bundesliga & 3135 \\
\hline 5 & France & Ligue 1 & 1920 \\
\hline 6 & Russia & Premier Liga & 1327 \\
\hline 7 & Turkey & Süper Lig & 1265 \\
\hline 8 & Portugal & Liga NOS & 1201 \\
\hline 9 & Brazil & Campeonato Brasileiro Serie A & 1141 \\
\hline 10 & Netherlands & Eredivisie & 707 \\
\hline 11 & Ukraine & Premier Liga & 677 \\
\hline 12 & Mexico & Liga MX Clausura & 647 \\
\hline 13 & Belgium & Jupiler Pro League & 613 \\
\hline 14 & Argentina & Primera Division & 603 \\
\hline 15 & Argentina & Torneo Inicial & 496 \\
\hline 16 & Greece & Super League & 408 \\
\hline 17 & Romania & Liga 1 & 323 \\
\hline 18 & Japan & J1 League & 285 \\
\hline 19 & USA & Major League Soccer & 282 \\
\hline 20 & Switzerland & Raiffeisen Super League & 260 \\
\hline 21 & China & Chinese Super League & 238 \\
\hline 22 & Colombia & Liga Postobon I & 222 \\
\hline 23 & Ecuador & Serie A Primera Etapa & 207 \\
\hline 24 & Czech Republic & Synot Liga & 204 \\
\hline 25 & Poland & Ekstraklasa & 201 \\
\hline 26 & Austria & Bundesliga & 197 \\
\hline 27 & Croatia & 1. HNL & 191 \\
\hline 28 & Norway & Tippeligaen & 188 \\
\hline 29 & Denmark & Alka Superligaen & 187 \\
\hline 30 & Uruguay & Primera Division Apertura & 187 \\
\hline 31 & South Korea & K-League Classic & 185 \\
\hline 32 & Serbia & SuperLiga & 178 \\
\hline 33 & Chile & Primera Division Clausura & 177 \\
\hline 34 & Scotland & Scottish Premiership & 172 \\
\hline 35 & Bulgaria & A Grupa & 166 \\
\hline 36 & Sweden & Allsvenskan & 156 \\
\hline 37 & Qatar & Qatar Stars League & 151 \\
\hline 38 & Israel & Ligat $\mathrm{HaAl}$ & 143 \\
\hline 39 & Peru & Torneo Descentralizado Apertura & 140 \\
\hline 40 & Saudi Arabia & Saudi Professional League & 133 \\
\hline
\end{tabular}


Table 5 continued

\begin{tabular}{|c|c|c|c|}
\hline Rank & Country & League & $\begin{array}{l}\text { Total market } \\
\text { value } \$ \mathrm{~m}\end{array}$ \\
\hline 41 & Iran & Persian Gulf Pro League & 132 \\
\hline 42 & Hungary & Nemzeti Bajnoksag & 130 \\
\hline 43 & Egypt & Egyptian Premier League & 129 \\
\hline 44 & South Africa & ABSA Premiership & 125 \\
\hline 45 & Cyprus & First Division & 113 \\
\hline 46 & Tunisia & Ligue Professionelle 1 & 105 \\
\hline 47 & Australia & A-League & 102 \\
\hline 48 & Algeria & Ligue Professionnelle 1 & 102 \\
\hline 49 & Kazakhstan & Premier Liga & 98 \\
\hline 50 & Morocco & Botola Pro & 86 \\
\hline 51 & Bosnia-Herzegovina & Premijer Liga & 84 \\
\hline 52 & Azerbaijan & Azerbaijan Premier League & 82 \\
\hline 53 & Slovenia & Prva Liga & 78 \\
\hline 54 & Belarus & Vysheyshaya Liga & 77 \\
\hline 55 & Costa Rica & Primera Division Invierno & 77 \\
\hline 56 & Slovakia & Fortuna Liga & 71 \\
\hline 57 & Macedonia & Prva Makedonska Fudbalska Liga & 52 \\
\hline 58 & Finland & Veikkausliiga & 50 \\
\hline 59 & Albania & Kategoria Superiore & 49 \\
\hline 60 & Georgia & Umaglesi Liga & 46 \\
\hline 61 & Moldova & Divizia Nationala & 45 \\
\hline 62 & New Zealand & ASB Premiership & 34 \\
\hline 63 & Armenia & Bardsragujn chumb & 34 \\
\hline 64 & Luxembourg & BGL Ligue & 33 \\
\hline 65 & Hong Kong & Hong Kong Premier League & 29 \\
\hline 66 & Lithuania & A Lyga & 28 \\
\hline 67 & Estonia & Premium Liiga & 24 \\
\hline 68 & Malta & Premier League & 21 \\
\hline 69 & Iceland & Pepsideild & 17 \\
\hline 70 & Ireland & League of Ireland & 15 \\
\hline 71 & Ghana & Premier League & 13 \\
\hline 72 & India & Indian Super League & 9 \\
\hline 73 & Northern Ireland & Danske Bank Premiership & 9 \\
\hline 74 & Wales & Welsh Premier League & 7 \\
\hline 75 & Faroe Island & Effodeildin & 4 \\
\hline 76 & Philippines & United Football League & 3 \\
\hline
\end{tabular}

Source: transfermarkt.co.uk. 
Table 6 Factors influencing attendance at national leagues

\begin{tabular}{lcr}
\hline Variable & Coefficients & $t$-statistic \\
\hline Intercept & 10.987 & 1.980 \\
Market value of players & 0.366 & 4.670 \\
FIFA rank of national team & 0.167 & 2.023 \\
Population & 0.399 & 6.365 \\
GDP per capita & 0.199 & 2.250 \\
Foundation date of federation & -0.003 & -1.373 \\
Africa & 0.780 & 2.649 \\
North, Central America & 0.180 & 0.512 \\
South America & -0.106 & -0.507 \\
Asia & -0.030 & -0.128 \\
$N$ & 57 & \\
$R^{2}$ adjusted & 0.857 & \\
\hline
\end{tabular}

Sources: Market value of players in 2015 was downloaded from http://www.transfermarkt.co.uk. FIFA rankings were downloaded from http://www.fifa.com. Population and GDP figures for 2014 were downloaded from http://www.worldbank.org. Total attendance at national leagues and the date of foundation of federation were downloaded from Wikipedia. The data are based on nine Asian nations, three African nations, 36 European nations, two from North, Central America and Caribbean, and seven from South America.

Notes: $N$ is the sample size, and $R^{2}$ is the coefficient of determination. FIFA, Fédération Internationale de Football Association; GDP, gross domestic product.

underlying factor. One candidate is the general popularity of the game. This is perhaps most obvious in the case of the USA, where football (soccer) is relatively minor sport. The national team is currently ranked 31st in the world. MLS was founded around the same time as the Japanese J-League, and has enjoyed a similar level of success, with the ninth highest attendance of any football league in the world (the J-League is 11th). But MLS has struggled for popularity with TV audiences, which are actually larger for broadcasts of the Mexican League and the English Premier League.

Another explanation is that the quality of league play is likely to be correlated with the success of the national team, since the majority of players in the national league come from that country (although in recent years the fraction has fallen below close to $50 \%$ in the English Premier League, this remains an exception). Thus, even if football is popular nationally, people may follow foreign leagues because the quality of domestic competition is not considered to be high. This is probably the case in much of Asia.

The diversity of Asian economies implies that these results should be interpreted with caution. Japan and Korea, in particular, have experienced some success in establishing national football leagues over the last 30 years, and enjoy both a high standard of living and have relatively large populations compared with many Asian countries. For them, one might argue, the most important way forward in the future is to bring in 
Table 7 Factors related to the performance of the national team

\begin{tabular}{lcr} 
Dependent variable: FIFA ranking & \\
\hline Variable & Coefficients & t Stat \\
\hline Intercept & & -0.11 \\
Population & -27.57 & -6.88 \\
GDP per capita & -12.34 & -4.79 \\
Foundation date of federation & -12.81 & 1.68 \\
Africa & 0.21 & 0.65 \\
North, Central America & 6.73 & 2.72 \\
South America & 27.33 & -0.78 \\
Asia & -10.48 & 7.88 \\
Oceania & 71.03 & 4.80 \\
$N$ & 78.77 & \\
$R^{2}$ & 182 & 0.590 \\
\end{tabular}

Sources: See note to Table 6. The data are based on 39 Asian nations, 53 African nations, 49 European nations, 24 from North, Central America and Caribbean, seven from Oceania, and 10 from South America.

Notes: $N$ is the sample size, and $R^{2}$ is the coefficient of determination. FIFA, Fédération Internationale de Football Association.

better players from abroad in order to raise the standard of play and attract larger crowds.

For China and India, the challenges seem a little different. The size of their populations gives them the potential to produce many great players, but they have so far failed to produce any. This reflects the limited soccer infrastructure in these countries. The recent decision by China to promote the playing of football in schools with the training of 50,000 additional coaches (AsiaNews.it, 2014) and the opening last year of the Indian Super League, the first national professional league, suggests that both countries may be warming to the global game.

The problem for the countries of the Gulf regions seems rather to be the opposite they have great wealth but relatively small populations. Climatic conditions are also unfavorable, notably exemplified by Qatar whose hosting of the World Cup in 2022 remains controversial partly for this reason.

Some further illumination is provided by examining the relationship between the ranking of the national team and underlying economic factors. Table 7 shows that the FIFA ranking of national teams depends significantly on population size and income (GDP per capita) - the coefficients are negative because a better rank implies a lower, not higher, number. What is striking is that history (measured by the foundation date of the national association) does not appear to have a significant impact on the ranking. Dummy variables for the continental federations of Asia, North America, and Oceania 
are significant (the control region is Europe). The Asian dummy is large and very significant, suggesting that teams from the continent perform very poorly relative to their population size and wealth.

This raises some interesting questions. Asia is a very diverse continent, and so it may be dangerous to infer too much from this grouping. However, it is striking to compare the progress of African teams to those of the Asian clubs (the North American experience seems primarily attributable to the cultural specificity of the USA). Europe and South America represented the established powers of football half a century ago. While Pele's famous prediction that an African team would win the World Cup by 2000 now seems wildly overoptimistic, the African teams have raised their performance in line with what could have been expected relative to their population size and wealth. Clearly, a major obstacle to progress remains the slow growth of their economies.

It seems likely that the performance of national football teams in Asia is ultimately a cultural phenomenon. In the market for professional footballers, careers start around the age of 17 , and players making their debut at this age have typically been devoted primarily to football for at least 4 or 5 years before, often much longer. Frequently, the focus on football leads to a relative neglect of schooling. In many Asian nations, by contrast a high premium is placed on school performance. This is reflected in global rankings such as the Programme for International Student Assessment (PISA) tests organized by the Organisation for Economic Cooperation and Development (OECD) to test 15 year olds in terms of Math, Science, and Reading. Out of 65 participating countries in 2012, Asian countries (specifically East Asian countries) dominated the top places. The top seven nations in Math were Asian, as were the top four in Science and the top five in reading (OECD, 2014).

On a more negative note, another factor holding back on the development of national leagues in Asia is probably the perception of corruption. This has been a particular problem in China, where match fixing, often related to illegal gambling, is seen to be rife. In a recent paper Elaad et al. (2015) showed that teams struggling to avoid relegation were more likely to succeed in critical games the higher Corruption Perception Index (produced by Transparency International) for that country. This suggests that corruption in general may be linked to positive outcomes which are particularly significant for clubs which might otherwise be unlikely to succeed. If domestic football leagues are linked to an environment of corruption fans are likely to be cynical and search for football entertainment elsewhere.

\section{Other Sports}

Yet another explanation for the low level of interest in national leagues in Asia is that there is interest in other sports. This certainly seems to be the case for some countries. For example, in India, Pakistan, Bangladesh, and Sri Lanka the dominant sport is cricket and so football attracts significantly less attention. Cricket is a game that originated in England and is also played at a high level in Australia, New Zealand, South Africa, the Caribbean as well as the Asian nations. ${ }^{11}$ While traditionally dominated by the English 
and Australians, it became clear in the 1980s that India would become the dominant power in the game largely because of its revenue-generating potential. In particular, cricket tours by the Indian national team are highly lucrative for the other nations because of the value of broadcast rights.

The dominant form of competition in cricket has traditionally been national team competition, the money from which was used to subsidize domestic competition which attracted a limited following and whose primary purpose was the development of young players for the national team. This led to a situation where the best players were badly underpaid and proved susceptible to match fixing organized by illegal Indian betting rings. Preston et al. (2001) proposed that one solution to this problem would be the creation of a club league competition that would serve to exploit demand for seeing the best players competing against each other. In 2008 the Indian Premier League (IPL) was created, immediately becoming the dominant competition in world cricket with broadcast right valued in excess of $\$ 1$ billion. While the IPL has faced some continuing problems, notably in relation to the allocation of franchises and allegations of match fixing, it has brought about a fundamental shift in the perception of the sport and led to an upsurge in popularity, at least in those nations where the game is already played. From the perspective of this paper, it shows that an Asian-based league can dominate a sport even though the origins of that sport are in Europe.

Two American sports have managed to achieve some penetration in Asia. Baseball gained a foothold in the 19th century in Japan where it remains the dominant sport. It has also had considerable success in Korea, Taiwan, and the Philippines but beyond that it has not spread widely in Asia. Without the global infrastructure of an organization such as FIFA, it seems unlikely that baseball will spread much further. Moreover, the dominance of Major League Baseball (MLB), the American organization, seems likely to inhibit local developments - any talent that emerges locally will automatically move to the USA. This can often be of benefit to interest in the game since fans will tune into MLB games to watch to local hero, but this is often at the expense of local teams (much the same can be said of Japanese and Korean football players who have moved to Europe).

The one American sport which seems to be making progress in Asia, especially China, is basketball. ${ }^{12}$ This is largely a function of the popularity of Yao Ming who played in the NBA from 2002 to 2011. Chinese basketball, like football, is beset by accusations of corruption. Against this, basketball has a strong following among the younger generation who tend to perceive it as "cool." Conceivably, this could propel the NBA to a preeminent position in global sport. Whether it could make basketball challenge the preeminence of football is more questionable.

\section{Conclusions on the Future of Asian Football Leagues}

Asian economic growth has transformed its relationship with the world economy. The global dominance of western powers, apparent since the early 19th century, is now beginning to wane. In many ways, my own country, Britain, is the precursor. Once the dominant power across the continent, its influence has shrunk to the point where it is 
barely noticed. Yet, as the historian AJP Taylor wrote in 1965 "By it [Association football] the mark of England may well remain in the world when the rest of her influence has vanished." Football is the world's sport, and European football leagues dominate the world and are presently led, in terms of revenue and global market penetration, by the English Premier League.

So could an Asian football league ever come to challenge this dominance in the way that a Toyota has overcome the western dominance of the car industry, in the way that Asian steel producers have come to dominate that industry, or the way that Asian real estate investors have become some of the key players around the globe? On the face of it is hard to see why not, and yet development has been slow.

I find this surprising because creating a dominant league is not technically difficult, it just requires a large sum of money. Football clubs are trophy assets, and it is clear that wealthy individuals in Asia are willing to spend large sums in order to achieve the recognition that goes with bankrolling a successful football club. True, so far the best examples come from the oil rich Gulf states - Sheikh Mansour of Abu Dhabi and Manchester City in England and Qatar Investment Fund and Paris St. Germain (France). Yet it will probably not be too long before a Chinese investor makes a statement of this kind.

The puzzle then, is why these investors do not want to do this in their own countries. For example, it is said that there are about 350 Chinese billionaires. If only $5 \%$ of them are interested in football that would be enough to create an 18-team league. If each puts $20 \%$ of their fortune into the league as start-up, and raised an equivalent sum in debt, the total would amount to at least $\$ 7$ billion - enough to fund the acquisition of some of the world's top talent and create a league that would be an attractive proposition to football fans in China and in much of the rest of the world. In India the original investors put in less than a billion to start the IPL and were instantly rewarded with broadcast rights valued at over $\$ 1$ billion, as well as almost unlimited, mostly positive, media exposure.

No doubt the existing football powers would go to great lengths to prevent such a move since it would undermine European dominance. But time and again players have shown that they are willing to go wherever the money is, and it is no longer clear that Europe has the financial muscle to win a bidding war. Currently the European governing body, UEFA, is trying to limit spending through its so-called Financial Fair Play regulations. This presents an opportunity for would-be rivals to bid away talent.

One answer to this puzzle may be that Asian investors are less keen to achieve publicity at home than abroad. There is an argument, for example, that the Russian oligarch Roman Abramovich chose to sink a large fraction of his wealth into Chelsea, and English club, rather than in Russia, precisely because it created a home for him in a more politically stable and liberal environment. It may be that wealthy individuals in some Asian countries prefer to make these kinds of investments abroad, just as one might go to Monte Carlo to gamble rather than betting online. This may also be connected to the issue of corruption and match fixing.

As things stand, without dramatically increasing the levels of investment, I think there is little prospect that Asian football leagues could prove a match for their European 
counterparts. However, my view is that one day this investment will be forthcoming, if only because Asians seem as a fanatical about the world's game as anyone else.

\section{Notes}

1 Four more teams were admitted in 1950, to bring it to the present total of 92 . In 1959 the bottom two tiers, which had hitherto been organized on a regional basis, became national. Then in 1992, the top division seceded from the Football League to form the Premier League. However, structurally the system was unchanged, since the mechanism of promotion and relegation was not changed. Other changes since 1923 include small changes in the number of clubs in each division, changes to the points system for determining rankings (from two points for a win to three) and the introduction of play-offs for promotion slots.

2 Good histories of the global spread of the game include Goldblatt (2008) and Murray (1994). Szymanski and Zimbalist (2006) reviewed the global development of the game in contrast to baseball.

3 In fact, it would be possible to gain entry at higher level, depending on the part of the country you lived in.

4 This contrasts, therefore, with the standard account of the economics sports leagues, which developed in the USA, which tends to focus on the point that teams require competitors, which we do not normally consider to be the case in other business enterprises.

5 The problems of endogeneity in this relationship is addressed by Peeters and Szymanski (2014).

6 The Chinese have long claimed to be the true inventors of the game, which they identify with Cuju, a game played with a ball that is kicked as long as 2500 years ago. China is not alone in being able to identify an ancient game which involved kicking a ball, and it seems reasonable to suppose that almost all cultures have invented some version of this. However, the modern game is explicitly based on the rules laid down in 1863 , and no ancient game which involved kicking a ball can be shown to relate very closely to these rules.

7 The Maddison-Project, http://www.ggdc.net/maddison/maddison-project/home.htm, 2013 version.

8 This website provides estimates of the market value of players based on fan opinions, and can be considered to be reasonable estimates of player values, at least when aggregated at the level of the league.

9 One other notable fact about the regression is that the dummy variable for Africa is significant, suggesting that there is a greater enthusiasm there than on other continents (the reference continent is Europe).

10 Kavetsos and Szymanski (2010) attempt to control for performance relative to expectations in the Olympics and in major football tournaments in determining subjective well-being, but find no significant effect. However, this may just be because defining expectations, and what represent performing above expectations, is so hard to measure.

11 While there are only 10 countries that play at the highest level, the International Cricket Council, which is the world governing body, has 110 members.

12 Historically, American football has made almost no impact outside the USA, although in recent years the National Football League (NFL) has achieved some following in Europe and there is talk of creating a franchise in London. The chances that the game will make a significant impact in Asia seem remote. Interestingly, the 1986 Superbowl was broadcast on national 
TV in China, preceded by a message from President Ronald Reagan, and is said to have reached an audience of 450 million (Accessed 31 July 2015. Available from URL: http://www.ozy.com/ flashback/the-day-china-watched-the-super-bowl/38942). It appears the experiment was not repeated.

\section{References}

AsiaNews.it (2014). To develop elite players, China boosts football training in schools. AsiaNews.it. 29 November 2014. Accessed 30 June 2015. Available from URL: http://www.asianews.it/newsen/To-develop-elite-players,-China-boosts-football-training-in-schools-32830.html

Elaad G., Kantor J. \& Krumer A. (2015). Does the corruption perception index predict the outcome of competitions? Evidence from a natural experiment around the world. Accessed 31 July 2015. Available from URL: http://ssrn.com/abstract $=2479747$

Goldblatt D. (2008). The Ball is Round: A Global History of Soccer. London: Penguin.

Kavetsos G. \& Szymanski S. (2010). National well-being and international sports events. Journal of Economic Psychology, 31 (2), 158-171.

Murray W. (1994). Football: A History of the World Game. Aldershot: Scolar Press.

OECD (2014). PISA 2012 results. Accessed 31 July 2015. Available from URL: http://www.oecd.org/ pisa/keyfindings/pisa-2012-results.htm

Peeters T. \& Szymanski S. (2014). Financial fair play in European football. Economic Policy, 29 (78), 343-390.

Preston I., Ross S. \& Szymanski S. (2001). Seizing the moment: A blueprint for reform of world cricket. Working paper, University College, London. Accessed 31 July 2015. Available from URL: http://www.ucl.ac.uk/ uctp100/bluprint.pdf\#search="University+of+College+London +Working+Paper+Cricket"

Sutton, J. (1991). Sunk costs and market structure: Price competition, advertising, and the evolution of concentration. MIT press.

Szymanski S. (2003). The economic design of sporting contests. Journal of economic literature, 41 (4), 1137-1187.

Szymanski S. (2015). Money and Soccer. New York: Nation Books.

Szymanski S. \& Zimbalist A. (2006). National Pastime: How Americans Play Baseball and the Rest of the World Plays Soccer. Washington, DC: Brookings Institution Press. 